\title{
Goiter depicted in Byzantine artworks
}

\author{
László G. Józsa
}

Department of Pathology, National Institute of Traumatology, Budapest, Hungary

\begin{abstract}
Pathologies depicted in sacral works of western civilisation are widely known. However, in this regard, the very rich and important Byzantine art, and particularly sacral art, has been largely ignored. Research carried out on 500 artworks has disclosed 119 pictures revealing 36 different physiological conditions (gravidity, labour) or pathological conditions (goiter, joint diseases, palsy etc.). Goiter, most likely as a result of iodine deficiency, is portrayed in 42 individuals (6 females, 14 males, 4 children and 18 angels). However, although the Byzantine sacral artworks give evidence of many pathological conditions, the diagnosed pathologies cannot be considered representative of the general population.
\end{abstract}

Key words: Byzantine icons, Endemic goiter, Frescoes

\section{INTRODUCTION}

Within the domain of sacred art, icons of Christ, the Virgin and the saints as well as of the story of the divine economy are characteristically accorded honour and veneration. With regard to their creation, their iconographic design has historically been dictated by the rules of Church tradition, declared by the Church Fathers at the Seventh Ecumenical Council in 878. ${ }^{1}$ On the other hand, man has always felt the need to express the events of his life, his experiences and emotions, in the form of pictures. Health and sickness, birth and death, invalidity, healing and recovery, development and aging, all being part of life, not surprisingly have always inspired man to portray these various manifestations. As in all western art, likewise, throughout

Address for correspondence:

László G. Józsa. Professor Emeritus of Pathology

H3648, Csernely, Táncsics u. 9. Hungary

e-mail: jozsalg@gmail.com

Received 09-07-10, Revised 00-00-10, Accepted 00-00-10 the period of Byzantine art, Byzantine artists, both major and minor, gave expression to these themes in their artistic productions. ${ }^{1}$ Thus, down through the centuries a vast number of artworks have been created that were indirectly related to medical matters.

The sacral artworks of western civilisation are well known in this regard. ${ }^{2-7}$ However, the very important and rich Byzantine art, especially sacral art, has not received analogous attention. I have found only one publication in which the Greek illustrations of human diseases in the artworks of Mount Athos were discussed. ${ }^{8}$

Nevertheless, because the artists' intention was to represent not pathological conditions but an individual personality and/or his/her sanctity, only a small number and aspect of the population's prevailing diseases (about 10 per cent) are actually visible on the depicted subjects (deformities of the musculoskeletal system, overweight, palsy, goiter etc.). The aim of the present study was to determine whether a collection of 
Byzantine icons may be a useful source for the study of the epidemiology of particular visible diseases.

\section{MATERIAL AND METHODS}

An observational evaluation of 500 Byzantine pictures (212 icons, 209 frescoes, 59 miniatures and 20 mosaics) was made. The majority of these artworks (480 paintings) originated from the post-iconoclastic period, i.e. the $10^{\text {th }}-16^{\text {th }}$ centuries. More than half (287) of the artworks I examined personally on the spot (Athens, Mount Athos, Meteora, Crete, Istanbul, Sicily, etc.) in monasteries, churches and museums while collecting from all artworks photographic documentation. The photos (whole fabric) have been gathered since 1978. In these pictures, 1,370 persons (712 males, 212 females, 73 children and 373 angels) were observable. First, evaluation was made of the general physical condition and skin colour, after which signs of anomalies of the eyes (strabismus, ptosis, exophthalmos, etc.) of the neck and face (goiter, cretinod appearance) and the overall appearance of the whole body (disproportionate physique, osseous deformation, thickened joints of the hand, etc.) were identified.

The symptoms of each disease where recorded following a standardised visual inspection and after examination of the photos under a stereomicroscope (Carl Zeiss Jena) by 2-5 fold magnification.

\section{RESULTS AND DISCUSSION}

Among 500 artworks, 122 pictures revealed 36 different physiological (gravidity, childbirth) or pathological (goiter, joint diseases, palsy, etc.) conditions.

In landlocked mountainous areas, iodine deficiency prevailed for many millennia, probably since the last glacial period..$^{10}$ The Balkans and the entire territory of the Byzantine Empire were particularly well known for occurence of severe endemic goiter as a result of iodine deficiency. ${ }^{7}$ Both Greek and Byzantine medical and civil (as well as legal) literature includes descriptions of goiter about 1000 years earlier than does western medical literature. ${ }^{6}$ Enlargement of the thyroid gland known as goiter appears in artworks of many cultures, with this condition being represented in numerous sculptures, bas-reliefs, paintings and draw- ings of the last few centuries. However, although these are described in Merke's monograph, ${ }^{7}$ the Byzantine sacral artworks displaying evidence of this and other medical conditions are largely ignored.

It is of interest to call to mind that the first pathological findings on goiter date back to the $6^{\text {th }}-7^{\text {th }}$ century by Aetii Amiendi and Paulus Aeginata who reported two types of endemic goiter. ${ }^{6}$ With regard to Byzantine sacral paintings, depictions of goiter appear very early, i.e. from the $7^{\text {th }}$ century (Figure 1), numerous sacral artworks bearing evidence of representation of (endemic) goiter. By contrast, such depictions do not appear in western altar paintings and frescoes until the end of the $15^{\text {th }}$ century. ${ }^{5}$ The medical condition of goiter was the most frequently painted bodily deformation appearing in Byzantine artworks, this being readily identifiable in saints, angels, children, the Virgin Mary and Christ. In total, 42 individuals (6 females, 14 males, 4 children and 18 angels) showed signs of either moderate or severe goiter. Among these one may identify 30 cases of diffuse goiter, four cases of congenital goiter (Figure 2) and eight of nodular goiter (Figure 3). A wall painting in the Stravronikita Monastery of Mount Athos shows among 12 persons four displaying signs of goiter. In icons representing the Nativity, in some cases the Virgin has a large circumferential goiter in the neck (Figure 4). Ten artworks reveal, besides signs of goiter, other pathologies such as osteoarthritis, strabismus, etc. evident on the same person. Exophthalmus due to Basedow-Graves' disease is frequently mentioned
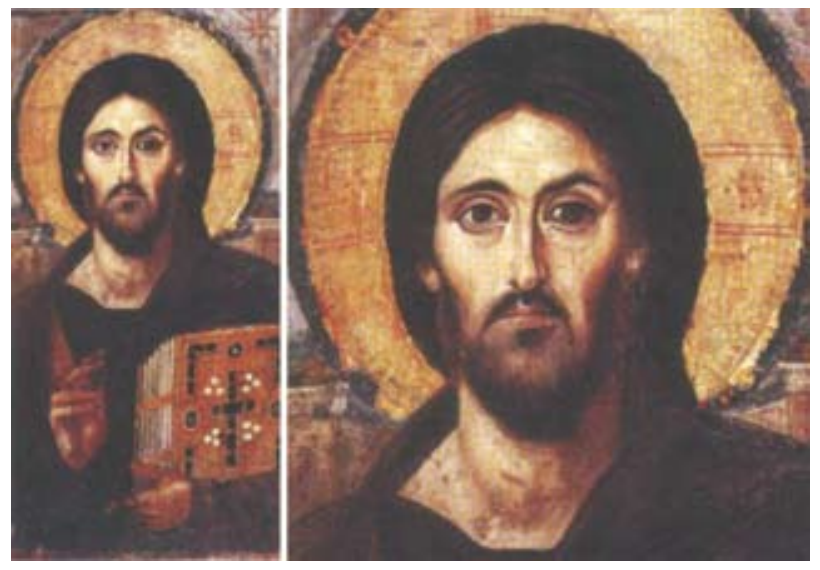

Figure 1. Icon of Christ. Diffuse goiter of the right lobe of the thyroid, St. Catherine's Monastery, Mount Sinai ( $7^{\text {th }}$ century). 


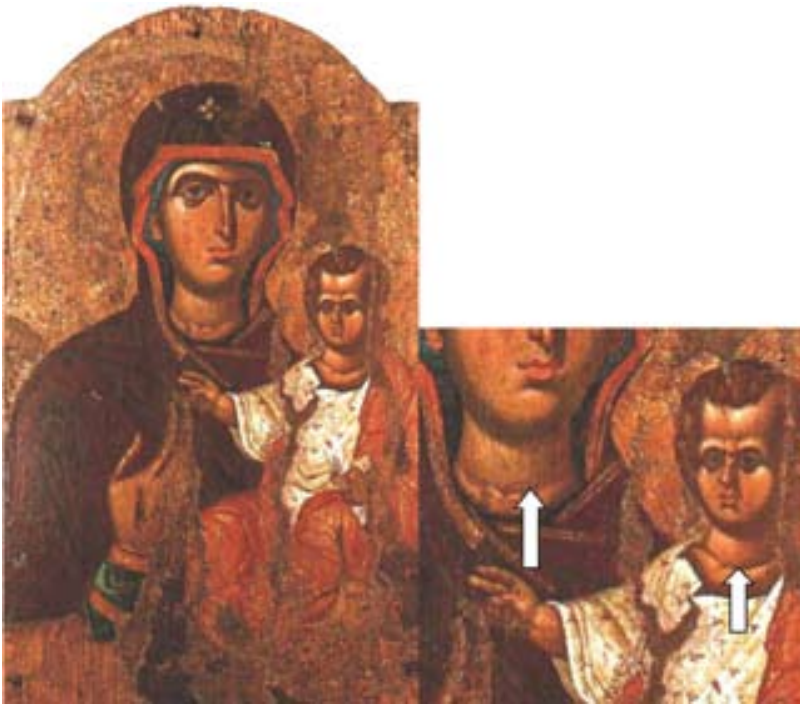

Figure 2. Virgo Hodegetria. $13^{\text {th }}$ century, icon. Philotheou Monastry, Mount Athos. Both the Virgin and Christ are portrayed with diffuse goiter. The Child probably has congenital goiter.

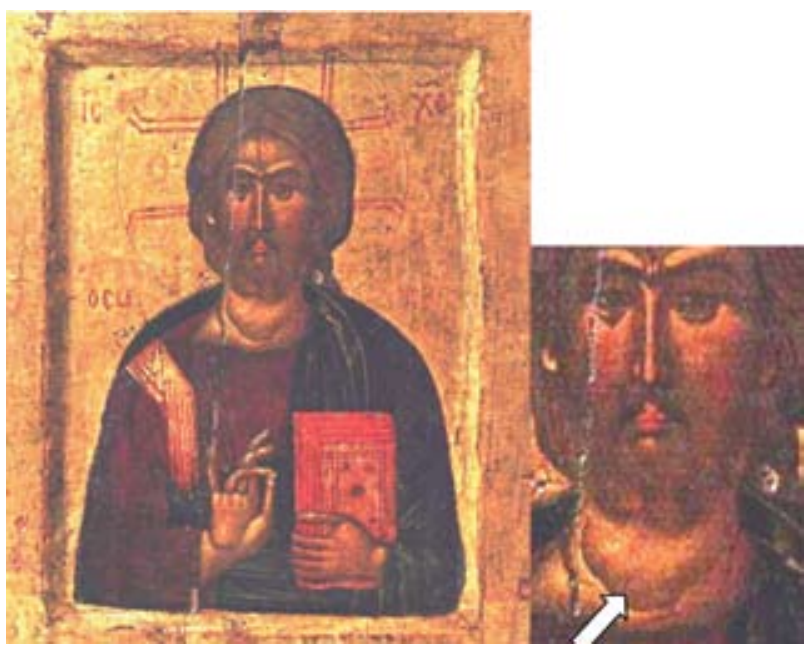

Figure 3. Christ Pantocratoras Icon. Great nodular goitre. Byzantine Museum, Athens (early $14^{\text {th }}$ century).

in the Byzantine literature; however, I found neither exophthalmus nor goiter with exophthalmus in any of the paintings.

The existence of holy icons as authentic expressions of Orthodox liturgical art is of considerable importance. These priceless icons, however, not only furnish the Orthodox interpretation of the word of truth and thus offer guidance to believers for the spiritual life. They are also a repository of extreme interest from

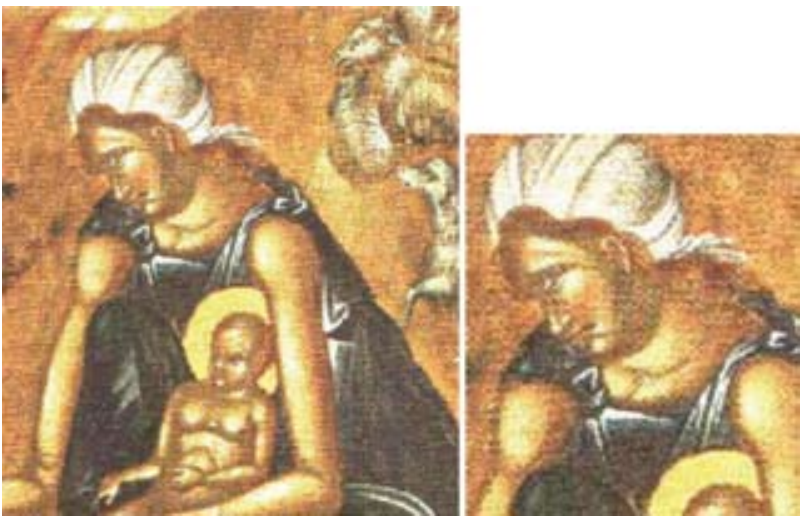

Figure 4. The icon representing the Nativity: the Virgin has a large circumferential goiter in the neck ( $15^{\text {th }}$ century).

the scientific and medical point of view since they are accurate depictions of the illnesses suffered by the inhabitants of the Byzantine Empire. Nevertheless, this aspect is unfamiliar to most scientists. While the history of art offers abundant discussions on the iconography, colours, composition, techniques of paintings and suchlike of the Byzantine icons, the pathological conditions evident in the portrayed persons are mostly uninvestigated. In previous articles I examined the visible deformities of the locomotor systems as represented in icons ${ }^{4}$ as well as depictions of childbirth and baby care, ${ }^{9}$ while another study in this field was published by Charlier. ${ }^{8}$ No other publications, however, can be found either in medical or in history of art literature dealing with the pathologies that are observable in Byzantine paintings. Thus, investigation and evaluation of Byzantine sacral art from this viewpoint remains largely an undiscovered territory.

The paintings were produced by both talented as well as less talented artists. Accordingly, signs of illnesses may often not have been reproduced appropriately owing to lack of artistic competence or else to artistic idealisation, in addition to the rigour of Church restraint: thus, signs of illnesses may not be easily detectable because body parts may have been represented in either an inexpert or else a nonstandard way. Clothing determined largely by the prevailing fashion also makes evaluation difficult. Another important limitation is the fact that artists did not reproduce signs of illnesses since to do so would have been regarded as stigmatising. Therefore, art- 
ists will often have tried to preserve or even increase the magnificence and dignity of their sitters by not representing their abnormality realistically.

In summary, a large number of pathological conditions can be identified in the Byzantine sacral artworks. However, the deformities illustrated in the artworks may not be representative of the status of the particular problem in the general population of the time.

\section{REFERENCES}

1. Vassilaki M 2005 (ed), Images of the Mother of God. Ashgate. Burlington

2. Als C, Stüssi YG, Tröhler U, Waber JH, 2002, Visible signs of illnesses from the $14^{\text {th }}$ to the $20^{\text {th }}$ century: systematic review of portraits. Brit J Med 325: 14991506.

3. Giampolmo A, Fulcheri E, 1988 An investigation of endemic goitre during the centuries in sacral figurative art. Zentralbl Allg Pathol Path Anat: 134: 297-307.

4. Józsa LG, 2006 Pathological alterations of locomotor systems in Byzantine paintings, miniatures and frescoes. Osteol Közl 14:1-10. (Hungarian with English summary).

5. Kuijjer PS, 1985 Sickness, medicine and pictorial art. Organorama 22: 13-20.

6. Marketos S, Eftychiadis A, Koutras DA, 1990 Thyroid diseases in the Byzantine era. J Roy Soc Med 83: 111113.

7. Merke F, 1984 History and iconography of endemic goitre and cretenism Hans Huber. Verl. Bern-StuttgartVienna.

8. Charlier P, 2003 The Greek illustrations of human diseases: Mount Athos Hist Sci Med 37: 105-122.

9. Jøzsa LG, 2007 Childbirth and baby-care portrayed in Byzantine sacral artworks. Orvosi Hetilap 148: 24832490. (Hungarian with English summary).

10. Langer P 1960 History of goitre. I: Endemic goitre. WHO Mon. Series. No 44. Geneva. 